\title{
Five new species of Culicoides Latreille described from Colombia, yielding a new species list and country records (Diptera: Ceratopogonidae)
}

\author{
Gustavo R Spinelli+, Erika Santamaría ${ }^{2}$, Olga L Cabrera², María M Ronderos ${ }^{1}$, Marco F Suárez $^{2}$ \\ 'División Entomología, Museo de La Plata, Paseo del Bosque s/n, 1900 La Plata, Argentina ²Laboratorio de Entomología, \\ Instituto Nacional de Salud, Bogotá, Colombia
}

The following five new species of Culicoides from Colombia are described, illustrated and placed to subgenus or species group: Culicoides antioquiensis, Culicoides gabrieli, Culicoides inermis, Culicoides micayensis and $\mathrm{Cu}$ licoides nigrifemur. C. gabrieli is also known from Peru. When possible, their position in previously published keys is indicated and their features discussed in light of the most recent revisions. A list of 180 Culicoides species known (114) or suspected of being in Colombia (66) is given in a Table. Of these, 12 including the new species are recorded from Colombia for the first time.

Key words: Culicoides - new species - new records - species list - biting midge - Colombia

Species in the genus Culicoides Latreille are by far the most notorious members of the 109 currently recognized extant genera of Ceratopogonidae. In the Neotropical region, Borkent and Spinelli (2007) recorded 266 species and Spinelli et al. (2007) described another species from Brazilian Amazonia. Seventy of these species are miserable pests of humans and domestic animals and seven of them serve as vectors of a variety of diseases, summarized by Borkent and Spinelli (2007).

There is no reliable, modern key to the subgenera and species groups of neotropical Culicoides. The only review of the genus for the region is the monography by Forattini (1957), but due to the numerous descriptions of new species and nomenclatorial actions by subsequent authors, this revision has not been updated. The easiest guide to species identification is that of Wirth et al. (1988), in which some meristic characters states and photographs of wings are provided. From there readers may refer to keys to subgenera or species groups, or species lists referred to local revisions from Panama (Wirth \& Blanton 1959), Amazon Basin (Wirth \& Blanton 1973), the Caribbean (Wirth \& Blanton 1974), Trinidad and Tobago (Aitken et al. 1975), Florida, USA (Blanton \& Wirth 1979), Colombia (Barreto 1986), South Amazon Basin (Spinelli \& Wirth 1986), Argentina (Spinelli et al. 2005) and Costa Rica (Spinelli \& Borkent 2004), among others.

In his catalog of the Culicoides from Colombia, Barreto (1986) recorded 88 species, and since then 14 species have to be added for a total of 102 Culicoides species presently known from Colombia. Although this is a relatively large number of species, at present their sanitary importance in Colombia appear to be restricted to the

+ Corresponding author: spinelli@fcnym.unlp.edu.ar

Received 20 August 2008

Accepted 23 December 2008 annoyance caused by the female biting habits. None of the recorded species has been irrefutably incriminated as a vector of pathogens, only Culicoides insignis Lutz is suspected to be involved in the transmissión of the bluetongue virus and the haemorragic fever virus to cattle (Homan et al. 1985), and Culicoides insinuatus Ortiz in the transmission of the filaroid Mansonella ozzardi to man (Tidwell \& Tidwell 1982).

A recent study of the collections of Culicoides from the Museo de La Plata, in La Plata, Argentina, and the Instituto Nacional de Salud, in Bogotá, Colombia, revealed the presence of five new species and an additional seven species not recorded yet to Colombia. The purpose of this paper is to provide the descriptions and records of this material, as well as an updated list of the 114 species inhabiting the country with their corresponding distribution. This list includes 66 species not formally recorded and expected to be discovered in Colombia.

\section{MATERIAL AND METHODS}

All specimens, mounted on microscope slides in Canada balsam, were examined and measured with a binocular compound microscope at 40-400X and drawings of certain diagnostic characters were prepared with an attached camera lucida. Wing photographs were taken with a Pentax Optio S 40, digital camera through a Leitz Wetzlar SM-LUX, binocular microscope.

Terms for structures follow those used in the Manual of Nearctic Diptera (McAlpine et al. 1981). Wing veins follow the system of the Manual of Nearctic Diptera, with modifications proposed by Szadziewski (1996). Names of veins are always in upper case and those of cells in lower case. Pale areas in cell $r_{3}$ posterior to or immediately distal to the 2 nd radial cell are called poststigmatic pale spots. Ratios used follow Spinelli et al. (1993).

Specimens were deposited, as noted, in the collections of the Instituto Nacional de Salud, Bogotá, Colombia (INS), and the Museo de La Plata, La Plata, Argentina (MLP). 


\section{Culicoides (Hoffmania) antioquiensis sp. n.,} (Figs 1-5, 11, 25)

Diagnosis: Only species in the hylas group with slender third palpal segment, apices of veins $\mathrm{M}_{1}, \mathrm{M}_{2}$ broadly pale, apex of $\mathrm{CuA}_{1}$ with small pale spot and apex of $\mathrm{CuA}_{2}$ dark, spermathecae without sclerotized necks, male tergite 9 with a distinct distal notch, gonostylus with subapical tooth and with V-shaped base of the separate portion of parameres.

Male: Similar to female with usual sexual differences. Wing length $1.19 \mathrm{~mm}$; width $0.41 \mathrm{~mm}$; CR 0.65 . Genitalia (Fig. 1): tergite 9 somewhat truncated, distinctly notched posteromedially, cerci pointed; sternite 9 with with shallow posteromedial excavation. Gonocoxite 2.4 times longer than broad; gonostylus yellow, slightly shorter than gonocoxite, nearly straight, with suabapical tooth, tip pointed. Parameres (Fig. 2) stout, broadly fused at base, fused portion 1.5 broader than long; separate portion $\mathrm{V}$-shaped at base, each abruptly tapering to terminal filament with very fine fringing hairs distally. Aedeagus triangular, 1.7 times longer than broad, progressively tapering, slender straight distal portion 0.22 times longer than total aedeagus length, apex with rounded papilla.

Female: head dark brown. Eyes (Fig. 11) bare, contiguous by distance equal to diameter of two ommatidia. Flagellum (Fig. 3) brown, bases of flagellomeres pale; AR 1.00; sensilla coeloconica on flagellomeres 1, 9-13. Palpus (Fig. 4) dark brown; third segment cylindrical, slender, sensilla scattered on surface; PR 4.15; P/H ratio 1.23. Mandible with 22 teeth. Scutum dak brown, with sublateral yellowish brown patches; scutellum, postscutellum dark brown. Legs dark brown; foreknee blackish with narrow pale ring on each side; midknee broadly yellowish on each side of joint; hindfemur dark to tip, hindtibia with narrow basal and apical pale rings; hind tibial comb with seven spines, second from spur longest. Wing (Fig. 25) length $1.40 \mathrm{~mm}$; width $0.60 \mathrm{~mm}$; CR 0.67; with contrasting pattern; pale spot over crossvein $\mathrm{r}-\mathrm{m}$ abutting wing margin; second radial cell in pale spot; $r_{3}$ with elongate pale spot anterior to base of $M_{1}$, distal pale spot in $r_{3}$ transverse, reniform, barely abutting wing margin; $\mathrm{M}_{2}$ straddled by pale spot nearly its midlength; distal pale spot in $\mathrm{m}_{1}$ broadly separated from wing margin; distal pale spot in $\mathrm{m}_{2}$ rounded, broadly

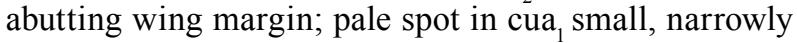
connected with narrow pale line bordering lower margin of $\mathrm{CuA}_{1}$; anal cell with two basal, two distal pale spots; apices of $\mathrm{M}_{1}, \mathrm{M}_{2}$ broadly pale, apex of $\mathrm{CuA}_{1}$ with small pale spot, apex of $\mathrm{CuA}_{2}$ dark; pale spot posterior to medial fork broadly connected with pale spot lying anterior to cubital fork. Macrotrichia sparce on distal half of wing, extending nearly to base of anal cell. Halter pale. Abdomen dark brown. Two ovoid, unequal spermathecae without sclerotized necks (Fig. 5), measuring 57 by $45 \mu$, and 46 by $39 \mu$; rudimentary third, ring present.

Distribution - Colombia; known only from the typelocality.
Type data and depository - Holotype male, allotype female, Colombia, Antioquia, near Rio Anori, tropic rain forest, IX-1970, DG Young, black light trap (MLP).

Taxonomic discussion-Culicoides antioquiensis sp.n. is a member of the hylas group of the subgenus Hoffmania Fox. This new species keys out in Wirth and Blanton (1968) to couplet 3 where is distinguished from Culicoides heliconiae Fox and Hoffman by the dark apex of vein $\mathrm{CuA}_{2}$ and from Culicoides palpalis Macfie by the small pale area in the apex of vein $\mathrm{CuA}_{\text {. }}$.

The male is very similar to C. palpalis, but in the latter species the tergite IX bears a very small, papilliform caudomedian process, the gonostylus lacks the subapical tooth and the base of the separate portion of parameres is rounded. The female of $C$. palpalis differs from the new species by the spermathecae with short and slender necks, by the distal pale area in cell $r_{3}$ broadly abutting wing margin and by the large pale spot in cua, broadly connected with the pale line bordering lower margin of $\mathrm{CuA}_{1}$.

The wing pattern of $C$. antioquiensis is similar to the one of Culicoides hylas, but the later species has dark mid knee and the third palpal segment bears an irregular sensory pit. The male of $C$. hylas has a small papilliform on posterior margin of tergite 9 and the fused proximal portion of the parameres is nearly as broad as long.

Etymology - The name of this species refers to Antioquia, the Department of the type-locality.

\section{Culicoides (Cotocripus) gabrieli sp. $\mathrm{n}$.}

(Figs 6-10, 12, 13)

Diagnosis: Only species in the subgenus Cotocripus Bréthes with narrowly separated eyes, five distal elongated flagellomeres, sensilla coeloconica on flagellomeres $1,5-8$, wing with pale areas nearly indistinguishable with macrotrichia very sparce on distal half, male sternite 9 with narrow notch, aedeagus triangular and distal portion of parameres slender without ventral lobe.

Male: Similar to female with usual sexual differences. Palpus (Fig. 8) brown, third segment swollen, with deep sensory pit opening by small pore. Wing length $0.77(0.74-$ $0.80, \mathrm{n}=2) \mathrm{mm}$; width $0.29(0.28-0.30, \mathrm{n}=2) \mathrm{mm} ; \mathrm{CR}$ $0.54(\mathrm{n}=2)$. Genitalia (Fig. 6): tergite 9 subquadrangular, distal margin convex, slender, apicolateral processes slender, subparallel, cerci elongate; sternite 9 with medial, narrow notch. Gonocoxite stout, 1.45 times longer than broad, ventral root stout, dorsal root slender, curved; gonostylus 1.2 times longer than gonocoxite, broad basally, distal portion slender, nearly straight. Parameres (Fig. 7) separate, each with scleotized basal knob, basal portion slender directed posteromesally, distal portion slender, sinuate, without ventral lobe, tapering to fine point without lateral barbs. Aedeagus triangular, lateral arms strongly sclerotized; basal arch rounded, extending 0.33 of total lentgh; distal portion with lateral pair of pointed processes, tapering to blunt tip.

Female: head dark brown. Eyes (Fig. 12) very narrowly separated, with numerous interommatidial spinules. Flagellum (Fig. 9) uniformly dark brown; flagellomeres 


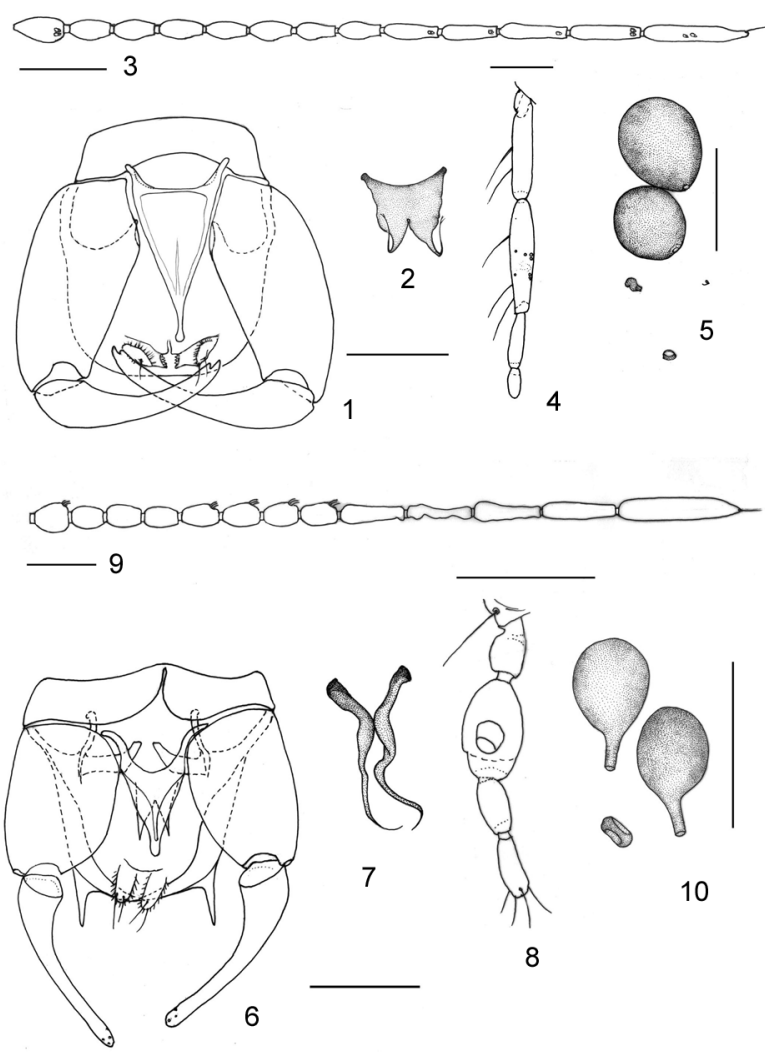

Figs 1-5: Culicoides antioquiensis; 6-10: Culicoides gabrieli; 1-2, 6-8: male; 3-5, 9-10: female; 1, 6: genitalia (parameres removed); 2, 7: parameres; 3, 9: flagellum; 4, 8: palpus; 5, 10, 14: spermathecae and ring; bars: $0.05 \mathrm{~mm}$.

2-8 short, vasiform, 9-13 subcylindrical; AR 1.30; sensilla coeloconica on flagellomeres 1, 5-8. Palpus brown; segments 3-5 missing; $\mathrm{P} / \mathrm{H}$ ratio 0.58 . Mandible with 14 teeth. Thorax uniformly dark brown. Legs dark brown; forefemur with faint subapical pale rings: fore, hind tibiae with subbasal pale rings; hind tibial comb with four spines, one nearest spur longest. Wing (Fig. 26) length $0.80 \mathrm{~mm}$; width $0.38 \mathrm{~mm}$; CR 0.65 ; with pale areas very much reduced, nearly indistinguishable over $\mathrm{r}-\mathrm{m}$ crossvein, poststigmatic area in $\mathrm{r}_{3}$, distally in, $\mathrm{m}_{1}, \mathrm{~m}_{2}$, cua ${ }_{1}$, anal cell. Macrotrichia very sparce, scattered on distal half of wing. Halter brown. Abdomen brown. Two pyriform, subeaqual spermathecae with sclerotized long necks (Fig. 10), each measuring 36 by $29 \mu$, neck $14 \mu$; rudimentary third, ring present.

\section{Distribution - Colombia (Chocó), Peru (Cuzco).}

Type data and depository - Holotype male, Peru, Cuzco, Kirigueti, 24-II-2004, J. Williams, at light (MLP); allotype female, Colombia, Chocó, Pié de Pepe, VI-1979, Cavelier, light trap (INS). Paratype, 1 male, same data as holotype (INS).

Taxonomic discussion - C. gabrieli sp. $\mathrm{n}$. is a member of the subgenus Cotocripus Brèthes. There is no available revision of the subgenus for the Neotropics,
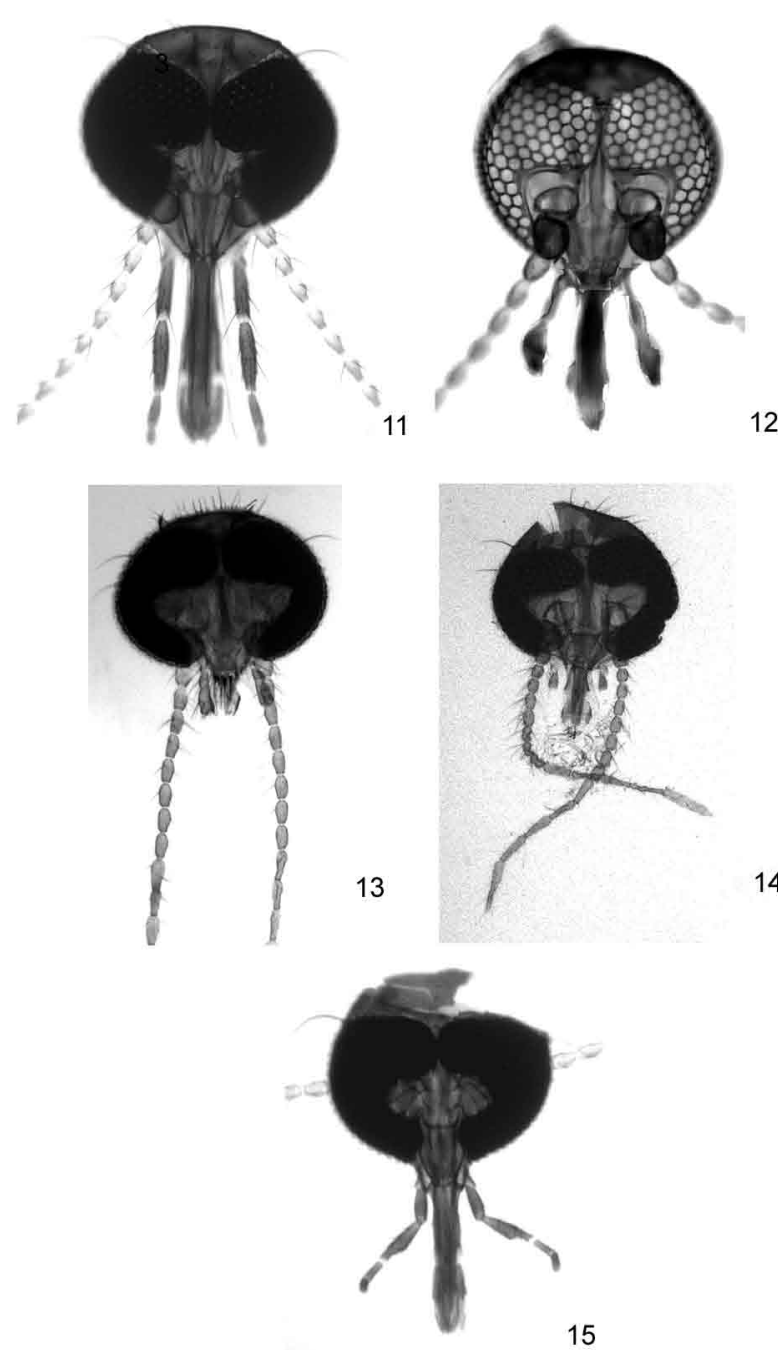

14

and according to Borkent and Spinelli (2007) five species are recognized in the region: Culicoides bambusicola Lutz, Culicoides caridei (Brèthes), Culicoides irwini Spinelli and Wirth, Culicoides patagoniensis Ronderos and Spinelli, and Culicoides raposoensis Wirth and Barreto. The wing pattern of $C$. gabrieli sp. n. is very similar to C. caridei and C. patagoniensis, very similar species from Southern South America. However, the female of these species shows well separated eyes, distinctly shorter flagellomeres 9-13 and the flagellomeres 11-13 bear sensilla coeloconica. The male genitalia of both species is also different, with the apicolateral processes of tergite 9 stouter, the sternites 9 lacking mesal notch, the aedeagus Y-shaped and shorter distal portion of parameres.

The male genitalia of $C$. bambusicola, a species inhabiting Eastern Brazil and Argentina, and Colombia and Venezuela, is similar to the one of C. gabrieli sp. $\mathrm{n}$. 
Nevertheless, the sternite 9 lacks the mesal notch and has stouter parameres. Regarding the female, the wing of $C$. bambusicola exhibits a distal rounded pale area in cell $\mathrm{r}_{3}$.

Culicoides raposoensis, a species also inhabiting Colombia, differs from C. gabrieli sp.n. by the cell $\mathrm{r}_{3}$ with a distal pale spot abutting wing margin, by the pale apex of the hindtibia, and by the male genitalia with parameres with well developed ventral lobe and aedeagus lacking lateral pointed processes.

Etymology - We are pleased to name this species after the Colombian writer Gabriel García Márquez, in recognition of his monumental literary work, the delight of several generations of readers around the World.

Culicoides (Anilomyia) inermis sp. $\mathrm{n}$.

(Figs 13, 16-18, 27)

Diagnosis: Only species in the decor group with sensilla coeloconica on flagellomeres $1,5-8$ and unarmed mandibles.

Male: unknown.

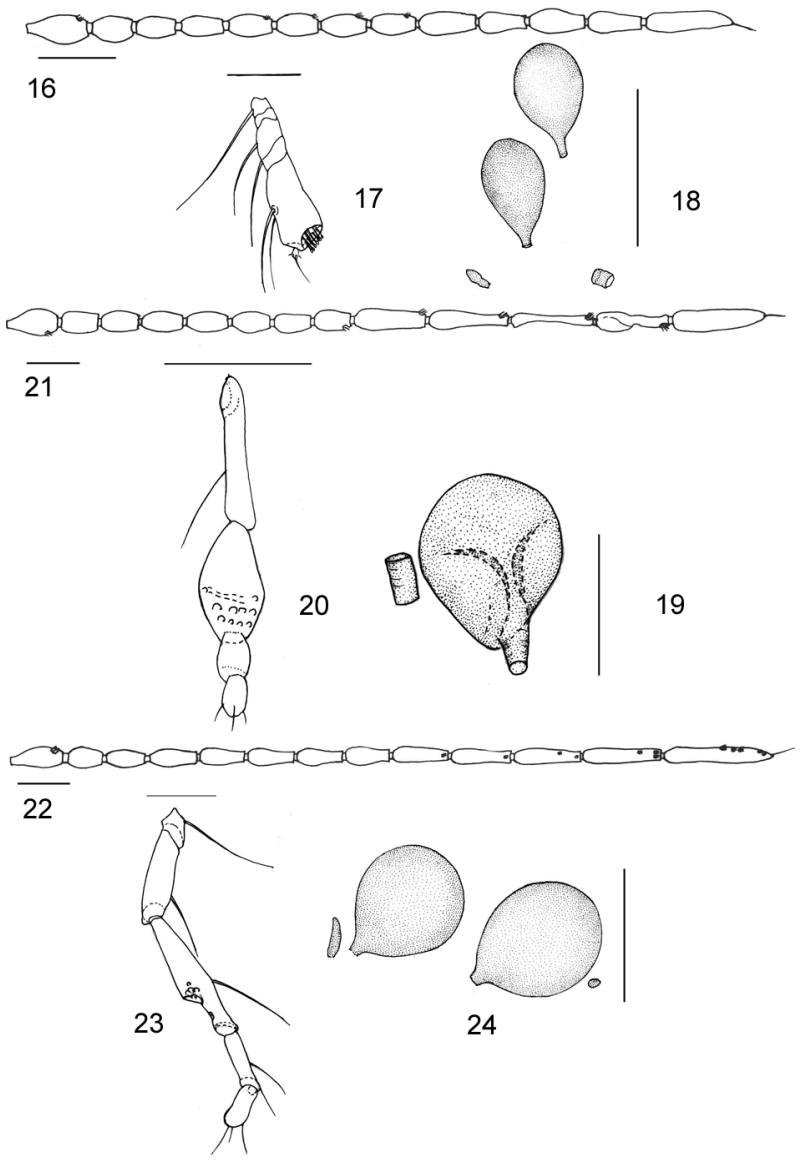

Figs 16-18: Culicoides inermis, female; 19-21: Culicoides micayaensis, female; 22-24: Culicoides nigrifemur, female. 16, 21, 22: flagellum; 17, 20, 23: palpus; 18, 19, 24: spermathecae and ring; bars: $0.05 \mathrm{~mm}$.
Female: head brown. Eyes (Fig. 13) bare, very narrowly contiguous. Flagellum (Fig. 16) uniformly brown; AR $0.91(0.85-1.07, \mathrm{n}=2)$; sensilla coeloconica on flagellomeres 1,5-8. Palpus (Fig. 17) brown; third seg-
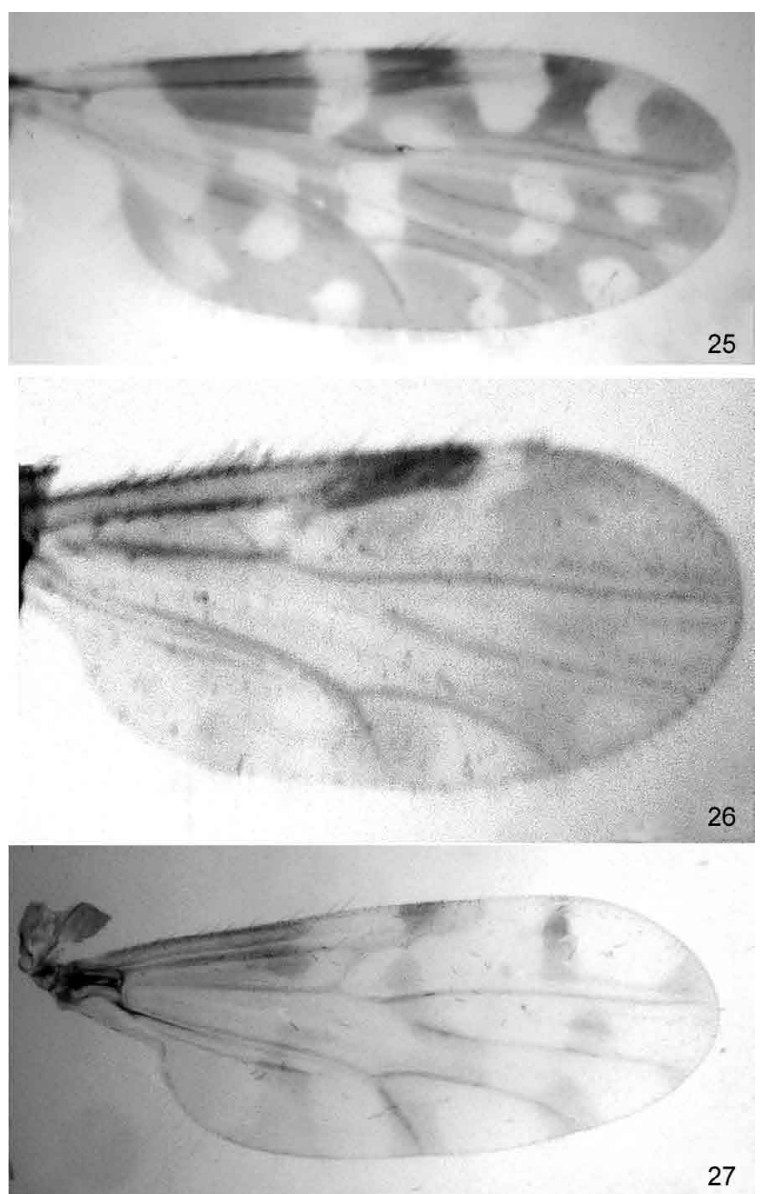

27
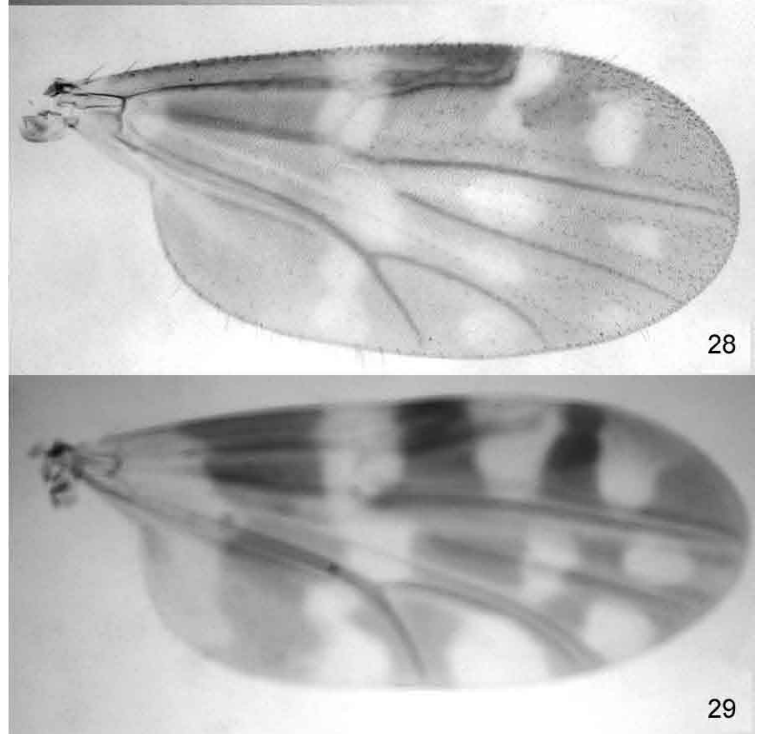

Figs 25-29: photographs of female wings of Culicoides from Colombia; 25: Culicoides antioquiensis; 26: Culicoides gabrieli; 27: Culicoides inermis; 28: Culicoides micayaensis; 29: Culicoides nigrifemur. 
ment slightly swollen distally, with apical sensory pit; segments 4-5 absent, only a minute stump bearing seta posterior to third segment in holotype; PR $1.60(\mathrm{n}=2)$; $\mathrm{P} / \mathrm{H}$ ratio $0.33(0.30-0.36, \mathrm{n}=2)$. Mandible without teeth. Thorax brown, scutum without definite pattern; postscutellum with transversal mesal dark brown patch. Legs brown; femora with faint subapical pale rings; tibiae with subbasal pale rings; hind tibial comb with seven spines, second from spur longest. Wing (Fig. 27) length 1.11 $(1.06-1.16, \mathrm{n}=2) \mathrm{mm}$; width $0.48(0.46-0.50, \mathrm{n}=2) \mathrm{mm}$; CR $0.62(n=2)$; predominantly pale, second radial cell in pale spot; three main transversal moderately dark areas extending from costa to distal wing margin: proximal one anterior to crossvein $\mathrm{r}-\mathrm{m}$, middle one from distal $1 / 4$ of $1 \mathrm{st}$ radial cell, distal one from midportion of $r_{3}$; apices of $r_{3}$, $\mathrm{M}_{2}$ moderately dark. Macrotrichia scarce on distal fourth of wing, only few marginal in $\mathrm{m}_{2}$, cua . Halter pale. Abdomen brown. Two ovoid spermathecae with sclerotized necks (Fig. 18), measuring $42(40-44, \mathrm{n}=2)$ by $32(31-33$, $\mathrm{n}=2) \mu$, neck $5 \mu$, and $39(37-41, \mathrm{n}=2)$ by $29(28-30, \mathrm{n}=$ 2) $\mu$, neck $4 \mu$; rudimentary third, ring present.

Distribution - Colombia, known only from the type-locality.

Type data and depository - Holotype female, Colombia, Valle, Rio Raposo, V-1965, VH Lee, light trap (MLP). Partype female, same data except VII-1965 (INS).

Taxonomic discussion - C. inermis sp. n. belongs in the decor species group of the subgenus Anilomyia, reviewed by for the Neotropics by Wirth and Blanton (1970). The antennal sensillar pattern 1,5-8 is unique in the subgenus. The wing pattern is nearly identical to Culicoides decor (Williston). However, apart from the different distribution of sensilla coeloconica whithin flagellomeres, C. inermis sp. n. is easily distinguished from $C$. decor by the shorter proboscis $(\mathrm{P} / \mathrm{H}$ ratio 0.85 in $C$. decor), unarmed mandibles (armed in C. decor) and by the maxillary palpus bearing only three well developed segments, with apical sensory pit in the third segment (with 5 developed segments in C. decor). These extra alar characteristics also distinguish $C$. inermis from other species in the group, all of them with palpus 5-segmented, armed mandibles and $\mathrm{P} / \mathrm{H}$ ratio ranging from $0.68-0.94$.

Etymology - This species is named inermis referring the unarmed mandibles.

\section{Culicoides micayensis sp. $\mathrm{n}$.}

(eublepharus group) (Figs 20-24)

Diagnosis: Only species in the eublepharus group with sensilla coeloconica on flagellomeres 1,(6) 8-12, 3rd palpal segment swollen at midlength with distal open sensory area, wing with only moderately distinct pattern of pale spots and with one spermatheca.

\section{Male: unknown.}

Female: head dark brown. Eyes (Fig. 14) with interommatidial spicules, very narrowly separated. Flagellum (Fig. 21) uniformly brown; flagellomeres 2-8 vasiform, subequal, 9-13 subcylindrical, elongate; AR 1.23 (1.18$1.28, \mathrm{n}=2)$; sensilla coeloconica on flagellomeres $1,(6)$
8-12. Palpus (Fig. 20) brown; third segment swollen at midlength, distal half with open sensory area on irregular concavity; PR $1.70(\mathrm{n}=2)$; P/H ratio $0.89(0.86-0.92$, $\mathrm{n}=2$ ). Mandible with 20 teeth. Thorax brown; scutum with admedian longitudinal, narrow, slightly paler patches. Legs brown; forefemur with subapical, faint pale ring; tibiae with subbasal pale rings; hind tibial comb with four spines, one nearest spur longest. Wing (Fig. 28) length $0.95(0.94-0.96, \mathrm{n}=2) \mathrm{mm}$; width $0.47(0.46-$ $0.48, \mathrm{n}=2) \mathrm{mm}$; CR $0.65(\mathrm{n}=2)$; brownish infuscated, with only moderately distinct pattern of pale spots; second radial cell in dark spot; pale spot over crossvein r-m small, barely abutting wing margin; poststigmatic pale spot in $r_{3}$ lying slightly obliquely, distal pale spot in $r_{3}$ transverse, not abutting wing margin or $\mathrm{M}_{1}$; two pa le spots in $\mathrm{m}_{1}$, distal one well separated from wing margin; $\mathrm{m}_{2}$, cua ${ }_{1}$, anal cell with distal, rounded pale spots abutting wing margin. Macrotrichia present on distal half of wing, few in cua ${ }_{1}$, anal cell, reaching in one row to base of $\mathrm{m}_{2}$. Halter brownish. Abdomen dark brown. One pyriform, partially collapsed spermathecae with sclerotized neck (Fig. 19), measuring 42 by $34 \mu$, neck $7 \mu$; rudimentary sperma-theca, ring present.

Distribution - Colombia, known only from the type-locality.

Type data and depository - Holotype female, Colombia, Cauca, López, Rio Micay, 16-V-1977, MA. Tidwell (MLP). Paratype female, same data except 16-V-1977 (INS).

Taxonomic discussion - C. micayensis sp. $\mathrm{n}$. is a member of the eublepharus group and unplaced to subgenus. The following four species of the eublepharus group also have one spermathecae: Culicoides archboldi Wirth and Blanton, Culicoides eublepharus Macfie, Culicoides guadeloupensis Floch and Abonnenc and Culicoides rangeli Ortiz and Mirsa. Of these the most similar is C. archboldi, but it is readily distinguished from C. micayensis by the sensilla coeloconica on flagellomeres 1,912 , by the absence of pale spots in cells $\mathrm{m}_{1}, \mathrm{~m}_{2}, \mathrm{cua}_{1}$, and anal cell, and by the long and coarse macrotrichia covering most of wing, reaching in two rows to base of cell $\mathrm{m}_{2}$. The wing pattern of C. micayensis sp. $\mathrm{n}$. is similar to the one of $C$. tamboensis, but the later species has two well developed spermathecae and bears sensilla coeloconica on flagellomeres 1,9 -12

Etymology - The name of this species refers to Rio Micay, the type-locality.

\section{Culicoides nigrifemur sp. n. (covagarciai group)}

(Figs 22-24)

Diagnosis: Only species in the covagarciai species group with third palpal segment slender, head and proboscis equal in length, and entirely dark hindfemur.

\section{Male: unknown.}

Female: head dark brown. Eyes (Fig. 15) bare, contiguous by distance equal to diameter of two ommatidia. Flagellum (Fig. 26) with flagellomeres 1-8 pale brown, 9-13 darker; AR 1.00; sensilla coeloconica on 
flagellomeres 1, 9-13. Palpus (Fig. 23) dark brown; 3rd segment slender, with irregular sensory pit; PR 4.30; P/H ratio 1.00. Mandible with 23 teeth. Thorax dark brown. Scutum apparently with mesal pale brown patch; scutellum, postscutellum dark brown. Fore and midlegs dark brown, with knees broadly pale yellow; hindfemur dark to tip, hindtibia pale yellow with mesal broad ring; hind tibial comb with six spines, second from spur longest. Wing (Fig. 29) length $2.26 \mathrm{~mm}$; width $1.04 \mathrm{~mm}$; CR 0.67; with contrasting pattern; pale spot over crossvein r-m broadly abutting wing margin; second radial cell in pale spot; distal pale spot in $\mathrm{r}_{3}$ transverse, brodly abutting wing margin; $\mathrm{M}_{2}$ straddled by pale spot nearly its midlength; distal pale spot in $\mathrm{m}_{1}$ somewhat elongate, broadly separated from wing margin; distal pale spot in $\mathrm{m}_{2}$ rounded, broadly abutting wing margin; pale spot in cua large, rounded, broadly abutting wing margin; anal cell with two distal pale spots; apices of $\mathrm{M}_{1}, \mathrm{M}_{2}, \mathrm{CuA}_{1}, \mathrm{CuA}_{2}$ dark; pale spot posterior to medial fork connected with pale spot lying anterior to cubital fork. Macrotrichia sparce on distal half of wing, absent in cua ${ }_{1}$, anal cell. Halter brown. Abdomen dark brown. Two ovoid, slightly unequal spermathecae with short necks (Fig. 24), measuring 62 by $48 \mu$, and 56 by $46 \mu$; rudimentary third, ring present.

Distribution - Colombia, known only from the type-locality.

Type data and depository - Holotype female, Colombia, Cauca, Páramo de Puracé, 28.4 km E Puracé, 3100 m, 18-II-1965, VH Lee, light trap (MLP).

Taxonomic discussion - C. nigrifemur sp. n. belongs in the covagarciai group of the subgenus Anilomyia, and is readily distinguished from the species included in that group by the entirely dark brown hindfemur and by the equal length of head and proboscis. Wirth and Blanton (1956d) reviewed the Culicoides covagarciai Ortíz species group for the Neotropics, and this new species keys out to Culicoides marshi Wirth and Blanton in couplet 2, with the exception that the proboscis of $C$. marshi is longer than its head. Besides that, the eyes are broadly contiguous in C. marshi, and only separated by two ommatidia in C. nigrifemur sp. n. The wing pattern of C. nigrifemur is nearly identical to the one of $C$. covagarciai, but apart from the different length of proboscis and legs coloration, C. covargaciai is easily distinguished from $C$. nigrifemur sp. $\mathrm{n}$. by its swollen third palpal segment.

Etymology - This species is named nigrifemur referring the uniformly dark coloration of the hindfemur.

\section{New records from Colombia}

Culicoides castillae Fox (fluvialis group)

C. castillae Fox 1946: 251 (female; Honduras); Forattini 1957: 499; Wirth and Blanton 1959: 416 (redesc.; synonymy; Panama; distr.); Wirth 1974: 29 (in catalog south to the USA); Wirth et al. 1988: 44 (numerical characters; wing photo; distr.); Borkent and Wirth 1997: 64 (in world catalog); Borkent and Spinelli 2000: 39 (in catalog south to the USA); Borkent and Spinelli 2007: 72 (in neotropical catalog).
Culicoides gibsoni Wirth 1952: 246 (female; Guatemala); Wirth 1955: 111 (male, redesc. female; Guatemala).

Culicoides flochabonnenci Ortiz and Mirsa 1952: 267 (female; Venezuela); Ortiz 1953: 801 (in key); Ortiz and León 1955: 574 (male, redesc. female; Ecuador).

Distribution - Guatemala to Ecuador, Venezuela, Trinidad.

New records - Colombia, Caquetá, Solano, 30-III1972, CJ Marinkelle, 1 female, light trap (INS); Boyacá, Pauna, Topo Grande, 29-VI-2006, M Suárez, 1 female, $\mathrm{CDC}+\mathrm{CO}_{2}$ (INS).

\section{Culicoides (Hoffmania) coutinhoi Barretto}

C. coutinhoi Barretto 1944: 96 (male; Brazil); Barbosa 1947: 13 (notes); Ortiz 1950: 449 (notes); Wirth and Blanton 1956a: 314 (female, male redesc.; French Guiana); Forattini 1957: 239 (erroneous synonym of lutzi); Wirth 1974: 24 (in catalog south to the USA); Spinelli and Wirth 1986: 52 (in key; wing photo); Wirth et al. 1988: 14 (numerical characters; distr.); Borkent and Wirth 1997: 65 (in world catalog); Spinelli et al. 1993: 28 (redesc.; distr.); Borkent and Spinelli 2000: 33 (in cata$\log$ south to the USA); Borkent and Spinelli 2007: 68 (in neotropical catalog).

Distribution - Colombia, French Guiana, Brazil (Amazonas, Pará, São Paulo).

New record - Colombia, Caquetá, San Vicente del Caguan, Tres Esquinas, 3-XII-1973, MF Suárez, 1 male (INS).

Note - The genitalia and the wing pattern of the specimen here recorded are identical to the ones described and illustrated in the original decription by Barretto (1944), as well as in the redescription by Spinelli et al. (1993). The only difference is the halter coloration, but as it was pointed out by Spinelli et al. (1993) this could be a variable character.

\section{Culicoides (Haematomyidium) filiductus Wirth}

C. filiductus Wirth, in Vitale et al. 1981: 155 (pupa, male, femle; Panama); Wirth et al. 1988: 48 (numerical characters; wing photo; distr.); Wirth and Felippe-Bauer 1989: 559 (redesc.; distr.); Borkent and Wirth 1997: 67 (in world catalog); Borkent and Spinelli 2000: 32 (in catalog south to the USA); Borkent and Spinelli 2007: 66 (in neotropical catalog).

Distribution - Belize to Colombia.

New record - Colombia, Amazonas, Leticia, II-1987, DG Young, 1 female, biting human (INS).

\section{Culicoides (Haematomyidium) germanus Macfie}

C. germanus Macfie 1940: 27 (female; Guyana); Wirth and Blanton 1956b: 188 (type redesc.; notes); Forattini 1957: 381; Wirth 1974: 31 (in catalog south to the USA); Vitale et al. 1981: 148 (in key debilipalpis group); Wirth et al. 1988: 48 (numerical characters; distr.); Borkent and Wirth 1997: 69 (in world catalog); Borkent 
and Spinelli 2000: 32 (in catalog south to the USA); Borkent and Spinelli 2007: 66 (in neotropical catalog).

Distribution - Costa Rica, Colombia, Guyana.

New record - Colombia, Tolima, Melgar, El Aguila, 19-II-1980, E Martínez, 1 female, biting human (INS).

\section{Culicoides leoni Barbosa (leoni group)}

C. leoni Barbosa 1952: 17 (female; Ecuador); Wirth and Blanton 1956c: 46 (male, female redesc.); Forattini 1957: 488; Wirth 1974: 33 (in catalog south to the USA); Wirth et al. 1988: 52 (numerical characters; wing photo; distr.); Borkent and Wirth 1997: 73 (in world catalog); Borkent and Spinelli 2000: 39 (in catalog south to the USA); Borkent and Spinelli 2007: 73 (in neotropical catalog).

Distribution - Colombia, Ecuador.
New records - Colombia, Boyacá, Pauna, Topo Grande, 29-VI-2006, M Suárez, 1 female, $\mathrm{CDC}+\mathrm{CO}_{2}$ (INS); Boyacá, Pauna, Aguasal, XII-2005, L Cuellar, 1 female, biting human (INS).

\section{Culicoides (Diphaomyia) mirsae Ortiz}

C. mirsae Ortiz 1953: 801 (female; Venezuela); Forattini 1957: 497; Wirth and Blanton 1959: 446 (redesc.; Panama; distr.); Wirth 1974: 34 (in catalog south to the USA); Wirth et al. 1988: 32 (numerical characters; wing photo; distr.); Borkent and Wirth 1997: 74 (in world catalog); Borkent and Spinelli 2000: 30 (in catalog south to the USA); Borkent and Spinelli 2007: 65 (in neotropical catalog).

Distribution - Panama, Venezuela, Colombia, Trinidad.

TABLE

List of Culicoides spp. known or suspected to occur in Colombia. Distributions are arranged North to South and West to East

Subgenus

Anilomyia Vargas

ameliae Browne; Colombia

chaverrii Spinelli and Borkent; Costa Rica ${ }^{a}$

chrysonotus Wirth and Blanton; El Salvador, Costa Rica, Panama ${ }^{a}$

covagarciai Ortiz; Honduras to Colombia, Venezuela

efferus Fox; Guatemala to Peru and Bolivia

inermis Spinelli; Colombia (NR)

lutealaris Wirth and Blanton; Costa Rica, Panama ${ }^{a}$

marshi Wirth and Blanton; Costa Rica, Panama, Colombia

metagonatus Wirth and Blanton; Nicaragua to Ecuador

monicae Spinelli and Borkent; Costa Rica ${ }^{a}$

nigrifemur Spinelli; Colombia. (NR)

nigrigenus Wirth and Blanton; Mexico (Veracruz) to Colombia, Trinidad, Argentina (Salta)

popayanensis Wirth and Lee; Colombia

rostratus Wirth and Blanton; Panama ${ }^{a}$

trapidoi Wirth and Barreto; Costa Rica, Colombia, Brazil

Avaritia Fox andicola Wirth and Lee; Colombia

hermani Spinelli and Borkent; Costa Rica, Panama ${ }^{a}$

orjuelai Wirth and Lee; Colombia

puracensis Wirth and Lee; Colombia

pusilloides Wirth and Blanton; Guatemala and Belize to Panama ${ }^{a}$

pusillus Lutz; USA (Florida), Mexico (Chiapas) to northeastern Argentina

suarezi Rodriguez and Wirth; Colombia

Cotocripus Brèthes bambusicola Lutz; Colombia, Venezuela, Brazil (Bahia, Espirito Santo, Rio de Janeiro, Sao Paulo), Argentina (Misiones, Buenos Aires)

gabrieli Spinelli; Colombia, Peru (NR)

raposoensis Wirth and Barreto; Colombia

Culicoides Latreille elutus Macfie; Mexico (Chiapas, Oaxaca) to Panama ${ }^{a}$

luteovenus Root and Hoffman; Mexico (DF, Oaxaca, Chiapas) to Panama

Diphaomyia Vargas evansi Wirth and Blanton; Honduras, Costa Rica, Panama ${ }^{a}$

iriartei Fox; Guatemala to Colombia, Venezuela, Tobagao, Brazil (Para)

marinkellei Wirth and Lee; Colombia

mirsae Ortiz; Panama, Venezuela, Trinidad (NR)

ronderosae Spinelli and Borkent; Costa Rica ${ }^{a}$

Drymodesmyia Vargas jamaicensis Edwards; USA (Texas, Florida), Mexico (Yucatán), Central America and

Caribbean to Colombia and Venezuela

panamensis Barbosa; Mexico (Nayarit, Veracruz, Chiapas) to Costa Rica, Jamaica ${ }^{a}$ 
pilosus Wirth and Blanton; Costa Rica, Panama, Brazil (Para)

poikilonotus Macfie; Mexico (Chiapas), Central America, Venezuela and Trinidad to Brazil (Bahia)

Glaphiromyia Vargas

Haematomyidium Goeldi scopus Root and Hoffman; Mexico (DF), Costa Rica, Panama ${ }^{a}$

annuliductus Wirth; Costa Rica, Panama ${ }^{a}$

bayano Wirth; Costa Rica, Panama ${ }^{a}$

darlingtonae Wirth and Blanton; Costa Rica, Trinidad ${ }^{a}$

debilipalpis Lutz; Widespread from USA (Maryland, Kentucky, Nebraska south to Lousi ana and Florida), Guatemala and Belize to Argentina

eldridgei Wirth and Barreto; Colombia

equatoriensis Barbosa; Ecuador ${ }^{a}$

filiductus Wirth; Belice to Panamá (NR)

germanus Macfie; Costa Rica, Guyana (NR)

ginesi Ortiz; El Salvador to Panama, Colombia, Venezuela, Trinidad, Brazil (Para), northeas tern Argentina

glabrior Macfie; Honduras to Ecuador, Guyana, Surinam, Trinidad, Brazil (Para)

hoffmani Fox; Belize, Costa Rica, Cayman Islands, Jamaica to Trinidad ${ }^{a}$

imitator Ortiz; Guatemala to Panama, Venezuela ${ }^{a}$

insinuatus Ortiz and León; Colombia, Ecuador, Peru, Trinidad, Guyana, Brazil (Amazonas, Para $^{b}$, Sao Paulo)

dlimonensis Ortiz and León; Ecuador, Venezuela, Brazil (Para, Sao Paulo, Santa Catarina) ${ }^{a}$ neoparaensis Tavares and Souza; Ecuador, Brazil (Amazonas, Rio de Janeiro, Santa Catarina) ${ }^{a}$ paraensis (Goeldi); USA (Colorado, Nebraska, Pennsylvania, Wisconsin to Louisiana and Florida) to Argentina

quasiparaensis Clastrier; Honduras and El Salvador to Colombia, Peru, French Guiana, Brazil (Amazonas, Rondonia)

spurius Wirth and Blanton; Costa Rica, Panama ${ }^{a}$

youngi Wirth and Barreto; Colombia

aitkeni Wirth and Blanton; Trinidad, Brazil (Amazonas) ${ }^{a}$

annettae Spinelli and Borkent; Costa Rica ${ }^{a}$

antioquiensis Spinelli; Colombia (NR)

batesi Wirth and Blanton; Guatemala, Colombia, Ecuador, Bolivia, Brazil (Para)

bimaculatus Floch and Abonnenc; Colombia, Brazil (Para), French Guiana ${ }^{b}$

brownei Spinelli; Colombia

coutinhoi Barretto; French Guiana, Brazil (Amazonas, Para, Sao Paulo) (NR)

davidi Spinelli; Costa Rica, Colombia, Trinidad

diabolicus Hoffman; Mexico to Venezuela and Ecuador

fernandoi Tavares and Souza; Colombia, Brazil (Espirito Santo, Rio de Janeiro, Santa Cata rina),

Northeastern Argentina, Uruguay

filarifer Hoffman; Mexico (Veracruz, Chiapas) to Northern Brazil

foxi Ortiz; Mexico (Chiapas) to Bolivia, Puerto Rico to Northeastern Argentina

franklini Spinelli; Mexico (Guerrero) to Bolivia, Brazil (Para)

fusipalpis Wirth and Blanton; El Salvador to Ecuador, Bolivia, French Guiana, Guyana, Brazil (Amazonas, Para, Bahia, Rio de Janeiro)

heliconiae Fox and Hoffman; Belize to Ecuador, Venezuela, Grenada, Trinidad and Tobago

hylas Macfie; Mexico (Veracruz) to Peru, Brazil (Amazonas)

ignacioi Forattini; Colombia, Brazil (Minas Gerais, Sao Paulo, Rio de Janeiro), Paraguay ${ }^{b}$

insignis Lutz; USA (Alabama, Georgia, Florida), Mexico (Yucatán, Chiapas), Central America and Caribbean to central Argentina

lutzi Costa Lima; Colombia to French Guiana, northeastern Argentina, Brazil (Roraima,

Amazonas, Para, Mato Grosso, Goias, Sao Paulo, Rio de Janeiro, Santa Catarina)

maruim Lutz; Venezuela to French Guiana, Trinidad, coastal Brazil ${ }^{a}$

ocumarensis Ortiz; Mexico (Oaxaca, Tabasco) to northern Brazil (Para, Rondonia)

palpalis Macfie; Mexico (Chiapas) to Peru, Brazil (Amazonas)

paraignacioi Spinelli; Belize to Colombia, French Guiana, Brazil (Amazonas, Para)

plaumanni Spinelli; Colombia, Bolivia, Brazil (Amazonas), northeastern Argentina (NR)

polypori Wirth and Blanton; Costa Rica to Colombia, Brazil (Amazonas)

pseudodiabolicus Fox; Mexico (Puente Nacional) to Peru and Northern Brazil

ruizi Forattini; Colombia, Brazil (Amazonas, Goias)

tidwelli Spinelli; Honduras to Colombia, Ecuador

travassosi Forattini; Surinam, Brazil (Amazonas, Para, Mato Grosso) ${ }^{a}$ 


\begin{tabular}{|c|c|}
\hline & $\begin{array}{l}\text { trinidadensis Hoffman; Coastal; Honduras and El Salvador to Colombia, Ecuador to } \\
\text { Surinam, Cuba and Cayman Islands to Trinidad } \\
\text { verecundus Macfie; Mexico (Chiapas) to Ecuador } \\
\text { xanifer Wirth and Blanton; Honduras to Panama }{ }^{a}\end{array}$ \\
\hline Macfiella Fox & $\begin{array}{l}\text { phlebotomus (Williston); Coastal; Mexico (Sinaloa) to Ecuador, Jamaica to Brazil (Maranhao, } \\
\text { Ceara, Pernambuco, Goias) } \\
\text { willistoni Wirth and Blanton; Mexico (Sonora), Honduras, Panama }{ }^{a}\end{array}$ \\
\hline Mataemyia Vargas & $\begin{array}{l}\text { avilaensis Ortiz and Mirsa; Venezuela }{ }^{a} \\
\text { azureus Wirth and Blanton; Panama }{ }^{a} \\
\text { bricenoi Ortiz; Ecuador, Venezuela, Bolivia, Brazil (Amazonas, Para) }{ }^{a} \\
\text { dalessandroi Wirth and Barreto; Costa Rica, Panama, Colombia } \\
\text { daviesi Wirth and Blanton; Peru, Guyana }{ }^{a} \\
\text { dicrourus Wirth and Blanton; Costa Rica to Ecuador } \\
\text { discrepans Ortiz and Mirsa; Venezuela }{ }^{a} \\
\text { mojingaensis Wirth and Blanton; Panama } \\
\text { volcanensis Wirth and Blanton; Panama, Colombia }\end{array}$ \\
\hline Oecacta Poey & $\begin{array}{l}\text { alahialinus Barbosa; Costa Rica, Panama, Colombia, Ecuador } \\
\text { barbosai Wirth and Blanton; USA (Florida) to Ecuador } \\
\text { cancer Hogue and Wirth; Mexico (Sinaloa), El Salvador, Costa Rica }{ }^{a} \\
\text { furens (Poey); USA (Massachusetts to Florida and Texas), Mexico (Campeche, Santiago, } \\
\text { Sinaloa, Yucatán, Veracruz) and Caribbean to Ecuador and coastal Brazil } \\
\text { gorgasi Wirth and Blanton; Costa Rica to Colombia }\end{array}$ \\
\hline Psychophaena Philippi & venezuelensis Ortiz and Mirsa; Costa Rica to Chile and Central Argentina \\
\hline \multicolumn{2}{|l|}{ Subgenus unplaced } \\
\hline acotylus group & $\begin{array}{l}\text { acotylus Lutz; Mexico (DF), Honduras, Panama, Venezuela, Trinidad, Surinam, Brazil } \\
\text { (Mato Grosso, Para) } \\
\text { carsiomelas Wirth and Blanton; Panam, Colombia, Brazil (Para) } \\
\text { teretipalpis Wirth and Barreto; Colombia }\end{array}$ \\
\hline carpenteri group & $\begin{array}{l}\text { belemensis Wirth and Blanton; Colombia, Brazil (Amazonas, Para) } \\
\text { camposi Ortiz and León; Costa Rica, Panama, Colombia, Ecuador } \\
\text { carpenteri Wirth and Blanton; Costa Rica, Panama, Ecuador, Bolivia, Brazil (Amazonas) }{ }^{a}\end{array}$ \\
\hline daedalus group & $\begin{array}{l}\text { antefurcatus Wirth and Blanton; Panama }{ }^{a} \\
\text { beaveri Wirth and Barreto; Colombia } \\
\text { commatis Wirth and Blanton; Panama }{ }^{a} \\
\text { crescentis Wirth and Blanton; Mexico (Chiapas) to Colombia, Northeastern Argentina } \\
\text { cummingi Spinelli and Borkent; Costa Rica }{ }^{a} \\
\text { daedaloides Wirth and Blanton; Panama, Colombia } \\
\text { daedalus Macfie; USA (Arizona, New Mexico), Mexico (Chiapas) to Colombia } \\
\text { dunni Wirth and Blanton; Costa Rica, Panama }{ }^{a} \\
\text { pampoikilus Macfie; USA (Arizona, New Mexico), Mexico (Chiapas, Oaxaca) to Venezuela }{ }^{a} \\
\text { phaeonotus Wirth and Blanton; Panama }{ }^{a} \\
\text { picadoae Spinelli and Borkent; Costa Rica }\end{array}$ \\
\hline dasyophrus group & $\begin{array}{l}\text { dasyophrus Macfie; Colombia, Ecuador, Venezuela, Guyana, Brazil (Amazonas, } \\
\text { Mato Grosso, Para) } \\
\text { rodriguezi Ortiz; Panama, Venezuela }{ }^{a}\end{array}$ \\
\hline eublepharus group & $\begin{array}{l}\text { caldasi Browne; Colombia } \\
\text { caucaensis Wirth and Lee; Colombia } \\
\text { eublepharus Macfie; Mexico (Chiapas), Costa Rica to Ecuador, Venezuela, northern Brazil } \\
\text { florenciae Messersmith; Colombia } \\
\text { micayensis Spinelli; Colombia (NR) } \\
\text { pabloi Browne; Colombia } \\
\text { propriipennis Macfie; Mexico (Chiapas) to Panama, Ecuador, Venezuela and northern Brazil }{ }^{a} \\
\text { rangeli Ortiz and Mirsa; Mexico (Oaxaca) to Ecuador, Bolivia, Venezuela, Trinidad, } \\
\text { Brazil (Amazonas). } \\
\text { tamboensis Wirth and Lee; Colombia } \\
\text { zumbadoi Spinelli and Borkent; Costa Rica }{ }^{a}\end{array}$ \\
\hline fluvialis group & balsapambensis Ortiz and León; Costa Rica to Ecuador, Brazil \\
\hline
\end{tabular}




\begin{tabular}{|c|c|}
\hline & $\begin{array}{l}\text { castillae Fox; Guatemala to Ecuador, Venezuela, Trinidad (NR) } \\
\text { fernandezi Ortiz; Venezuela }{ }^{a} \\
\text { fluvialis Macfie; Honduras to Colombia, Venezuela, Trinidad, Guyana, } \\
\text { Brazil (Amazonas, Para) } \\
\text { leopoldoi Ortiz; Guatemala and Belize to Bolivia and Northeastern Argentina, Trinidad } \\
\text { lichyi Floch and Abonnenc; Venezuela }{ }^{a} \\
\text { tetrathyris Wirth and Blanton; Honduras, Costa Rica, Panama, Ecuador, Trinidad, } \\
\text { Surinam, northern Brazil }{ }^{a} \\
\text { yaracuyensis } \text { Ortiz; Venezuela }^{a}\end{array}$ \\
\hline leoni group & $\begin{array}{l}\text { benarrochi Oritz and Mirsa; Brazil (Rio de Janeiro), Venezuela, Trinidad }{ }^{a} \\
\text { fieldi Wirth and Blanton; Honduras, Costa Rica, Panama } \\
\text { gabaldoni Ortiz; Mexico (Tabasco) to Ecuador, Venezuela, Trinidad, Brazil (Bahia), } \\
\text { Paraguay, northeastern Argentina } \\
\text { glabellus Wirth and Blanton; Honduras to Ecuador, Trinidad, Brazil (Bahia, Para) } \\
\text { leoni Barbosa; Ecuador (NR) } \\
\text { trifidus Spinelli and Borkent; Costa Rica }{ }^{a}\end{array}$ \\
\hline limai group & $\begin{array}{l}\text { galindoi Wirth and Blanton; Costa Rica, Panama } \\
\text { limai Barretto; El Salvador to Ecuador, Brazil (Para, Mato Grosso, Sao Paulo, Rio de Janeiro, } \\
\text { Santa Catarina) to northeastern Argentina } \\
\text { santanderi Browne; Colombia } \\
\text { tenuilobus Wirth and Blanton; Guatemala to Panama }{ }^{a} \\
\text { vernoni Wirth and Blanton; Costa Rica, Colombia, Bolivia, Brazil (Para) }\end{array}$ \\
\hline monticola group & $\begin{array}{l}\text { andinus Wirth and Lee; Colombia } \\
\text { magnipalpis Wirth and Blanton; Panama }{ }^{a} \\
\text { monticola Wirth and Lee; Costa Rica to Ecuador }\end{array}$ \\
\hline pachymerus group & $\begin{array}{l}\text { almirantei Wirth and Blanton; Costa Rica, Panama }{ }^{a} \\
\text { atelis Wirth; Panama }{ }^{a} \\
\text { caprilesi Fox; Panama, Colombia, Venezuela, Brazil (Para, Mato Grosso) obnoxius Fox; Colombia, } \\
\text { Venezuela } \\
\text { pachymerus Lutz; Guatemala to Colombia, Brazil (Amazonas) } \\
\text { uniradialis Wirth and Blanton; Panama, Colombia }\end{array}$ \\
\hline reticulatus group & $\begin{array}{l}\text { aureus } \text { Ortiz; Mexico (Nayarit), Panama, Bolivia, Venezuela, Paraguay, Brazil (Amazonas), } \\
\text { northeastern Argentina }^{a} \\
\text { forattinii Ortiz; Venezuela }^{a} \\
\text { guyanensis Floch and Abonnenc; Panama, Venezuela to French Guiana, Trinidad and Tobago, } \\
\text { Brazil (Para, Pernambuco, Sao Paulo) } \\
\text { lanei Ortiz; Mexico (Veracruz), Honduras, Costa Rica, Panama, Venezuela, Trinidad, Brazil (Para) }^{a} \\
\text { lyrinotatus Wirth and Blanton; Nicaragua, Panama, Brazil }^{a} \\
\text { macrostigma Wirth and Blanton; Costa Rica to Colombia } \\
\text { paucienfuscatus Barbosa; Costa Rica to Peru and Bolivia,Venezuela, Trinidad, Brazil } \\
\text { (Amazonas, Para) } \\
\text { pifanoi Ortiz; Belize to Colombia, Venezuela, Trinidad, Brazil (Para, Bahia), Paraguay } \\
\text { reticulatus Lutz; Honduras to Colombia, Brazil (Pernambuco, Bahia, Sao Paulo, } \\
\text { Rio de Janeiro) }\end{array}$ \\
\hline stigmalis group & $\begin{array}{l}\text { alvarezi Ortiz; Ecuador, Venezuela }{ }^{a} \\
\text { fluviatilis (Lutz); Colombia, Ecuador, Bolivia, Venezuela, Trinidad, Brazil (Amazonas) } \\
\text { stigmalis Wirth; Mexico (Oaxaca), Guatemala, Costa Rica, Panama }{ }^{a}\end{array}$ \\
\hline
\end{tabular}

Miscellaneous unplaced species

arubae Fox and Hoffman; USA (Texas), Mexico (Yucatán), Aruba and Grenada,

to Colombia and Venezuela

malariologiensis Perruolo; Venezuela ${ }^{a}$

pancensis Browne; Colombia

trilineatus Fox; Guatemala to Panama, Puerto Rico, Virgin Islands, Dominica, Barbados, Paraguay ${ }^{a}$ unetensis Perruolo; Venezuela ${ }^{a}$

wokei Fox; Costa Rica, Panama ${ }^{a}$

$a$ : species not formaly recorded, expected to be discovered in Colombia; $b$ : species recorded from Colombia, their formal record herein considered doubtful; NR: new record for Colombia, although in some instances, the species has been previously recorded from both North and South of Colombia. Also includes the five new species herein described. 
New records - Colombia, Boyacá, Otanche, Cortaderal, 10-I-2006, Y Sosa, 1 female, biting human (INS).

\section{Culicoides (Hoffmania) plaumanni Spinelli}

C. plaumanni Spinelli, in Spinelli et al. 1993: 69 (female; Argentina); Spinelli and Wirth 1993: 35 (in list Argentina); Spinelli 1998: 325 (in list Argentina); Spinelli et al. 2005: 139 (in key Argentina); Borkent and Wirth 1997: 79 (in world catalog); Borkent and Spinelli 2000: 34 (in catalog south to the USA); Borkent and Spinelli 2007: 69 (in neotropical catalog); Felippe-Bauer et al. 2008: 36 (records Peru).

Distribution - Colombia, Peru, Bolivia, Brazil (Amazonas), Northeastern Argentina.

Newrecords -Colombia, Meta, Villavicencio, El Buque, IV-1978, MF Suárez, 1 female, Shannon trap (INS).

\section{REFERENCES}

Aitken THG, Wirth WW, Williams RW, Davies JB, Tikasingh ES 1975. A review of the bloodsucking midges of Trinidad and Tobago, West Indies (Diptera: Ceratopogonidae). J Entomol (B) 44: 101-144.

Barbosa FAS 1947. Culicoides (Diptera: Heleidae) da região neotropical. Ann Soc Biol Pernambuco 7: 3-30.

Barbosa FAS 1952. Novos subsídios para o conhecimento dos Culicoides neotrópicos (Diptera: Heleidae). Thesis, Univ. Recife, Imprensa Industrial, Recife, $21 \mathrm{pp}$.

Barreto MD 1986. Catálogo de los Culicoides (Diptera: Ceratopogonidae) de Colombia. Colombia Méd 17: 140-150.

Barretto MP 1944. Sobre o género Culicoides Latreille, 1809, com a descrição de trés novas espécies (Diptera, Ceratopogonidae). Ann Fac Med Univ São Paulo 20: 89-105.

Blanton FS, Wirth WW 1979. The sand flies (Culicoides) of Florida (Diptera: Ceratopogonidae), Vol. 10, Arthropods of Florida and neighboring land areas, Florida Department of Agriculture and Consumer Services, Division of Plant Industry, Gainesville, 204 pp.

Borkent A, Spinelli GR 2000. Catalog of new world biting midges South of the United States (Diptera: Ceratopogonidae). Contrib Entomol Internat 4: 1-107.

Borkent A, Spinelli GR 2007. Neotropical Ceratopogonidae (Diptera: Insecta). In J Adis, JR Arias, G Rueda-Delgado, KM Wnatzen, Aquatic biodiversity in Latin America (ABLA), Vol. 4, Pensoft, Sofia-Moscow, p. 1-198.

Borkent A, Wirth WW 1997. World species of biting midges (Diptera: Ceratopogonidae). Bull Am Mus Nat Hist 233: 1-257.

Felippe-Bauer ML, Cáceres G, Silva CS, Valderrama Bazan W, Gonzales-Perez A, Silva JM 2008. New records of Culicoides Latreille (Diptera: Ceratopogonidae) from Peruvian Amazonian region. Biota Neotrop 8: 33-38.

Forattini OP 1957. Culicoides da região neotropical (Diptera: Ceratopogonidae). Arq Fac Hig Saude Pub Univ São Paulo 11: 159-526.

Fox I 1946. A review of the species of biting midges or Culicoides from the Caribbean Region (Diptera: Ceratopogonidae). Ann Entomol Soc Am 39: 248-258.

Homan EJ, Taylor WP, De Ruiz L, Yuill TM 1985. Bluetongue virus and epizootic haemorrhagic disease of deer virus serotypes in Northern Colombian cattle. J Hyg 95: 165-72.

Macfie JWS 1940. A report on a collection of Ceratopogonidae (Diptera) from British Guiana. Entomol Mo Mag 76: 23-32.
McAlpine JF, Peterson BV, Shewell GE, Teskey HJ, Vockeroth JR, Wood DM 1981. Manual of Nearctic Diptera, Vol. 1, Agriculture, Monograph 27, Research Branch Agriculture Canada, Otawa, 674 pp.

Ortiz I 1950. Estudios en Culicoides IV. Revisión de las especies americanas del sub-género Hoffmania Fox 1948, con la descripción de dos nuevas especies. Rev San Asist Soc 15: 437-460.

Ortiz I 1953. Nueva contribución al conocimiento de los caracteres morfológicos externos de las hembras americanas del género Culicoides Ltr (Diptera: Ceratopogonidae) con una espermateca. Descripción de dos nuevas especies de Venezuela: Culicoides transferrans (C. oublepharus [sic] Ortiz, 1952) y Culicoides mirsae. Rev San Asist Soc 18: 797-806.

Ortiz I, León LA 1955. Los Culicoides (Diptera: Ceratopogonidae) de la República del Ecuador. Bol Inf Cient Nac 7: 564-594.

Ortiz I, Mirsa M 1952. Culicoides de Venezuela - Redescripción de 10 especies con la descripción de algunos sexos no conocidos. Rev San Asist Soc 17: 257-279.

Spinelli GR 1998. Ceratopogonidae. In S Coscarón, JJ Morrone. Biodiversidad de los artrópodos argentinos. Una aproximación biotaxonómica, Ediciones Sur, La Plata, p. 314-326.

Spinelli GR, Borkent A 2004. New species of Central American Culicoides Latreille (Diptera: Ceratopogonidae) with a synopsis of species from Costa Rica. Proc Entomol Soc Wash 106: 361-395.

Spinelli GR, Greiner EC, Wirth WW 1993. The Neotropical bloodsucking midges of the Culicoides guttatus group of the subgenus Hoffmania (Diptera: Ceratopogonidae). Contrib Am Entomol Inst 27: 1-91.

Spinelli GR, Ronderos MM, Díaz F, Marino PI 2005. The bloodsucking biting midges of Argentina (Diptera: Ceratopogonidae). Mem Inst Oswaldo Cruz 100: 137-150.

Spinelli GR, Ronderos MM, Marino PI, Silveira Carrasco D, Menezes Ferreira RL 2007. Description of Culicoides (Mataemyia) felippebauerae sp. n., Forcipomyia musae immatures, and occurrence of $F$. genualis, breeding in banana stems in Brazilian Amazonia (Diptera: Ceratopogonidae). Mem Inst Oswaldo Cruz 102: 659-669.

Spinelli GR, Wirth WW 1986. Clave para la identificación de las especies del género Culicoides Latreille presentes al sur de la cuenca Amazónica. Nuevas citas y notas sinonímicas (Diptera: Ceratopogonidae). Revta Soc Entomol Argent 44: 49-73.

Spinelli GR, Wirth WW 1993. Los Ceratopogonidae de la Argentina (Insecta: Diptera). In ZA de Castellanos, Fauna de agua dulce de la República Argentina, Vol. 38, Fasc. 3, Profadu (Conicet), La Plata, p. 1-121.

Szadziewski R 1996. Biting midges from lower cretaceous amber of Lebanon and upper cretaceous Siberian amber of Taimyr (Diptera: Ceratopogonidae). Studia Dipterol 3: 23-86.

Tidwell MA, Tidwell MA 1982. Development of Manzonella ozzardi in Simulium amazonicum, S. argentiscutum and Culicoides insinuatus from Amazonas, Colombia. Am J Trop Med Hyg 31: 1137-1141.

Vitale GC, Wirth WW, Aitken THG 1981. New species and records of Culicoides reared from arboreal habitats in Panama, with a synopsis of the debilipalpis group (Diptera: Ceratopogonidae). Proc Entomol Soc Washington 83: 140-159.

Wirth WW 1952. Two new species of anthropophilic Culicoides from Guatemala (Diptera: Heleidae). J Parasitol 38: 245-247.

Wirth WW 1955. Report on a collection of biting midges of the genus Culicoides from Guatemala. Proc Entomol Soc Wash 57: 109-117. 
Wirth WW 1974. Family Ceratopogonidae. In N Papavero, A catalog of the Diptera of the Americas South of the United States, Fasc. 14, Museu de Zoologia da Universidade de São Paulo, São Paulo, p. 1-89.

Wirth WW, Blanton FS 1956a. Studies in Panama Culicoides. VIII. The Neotropical species of the guttatus group of the subgenus Hoffmania (Diptera: Heleidae). Proc Entomol Soc Wash 58: 305-326.

Wirth WW, Blanton FS 1956b. Redescriptions of four species of neotropical Culicoides of the debilipalpis group (Diptera: Heleidae). J Washington Acad Sci 46: 186-190.

Wirth WW, Blanton FS 1956c. Studies in Panama Culicoides (Diptera: Heleidae). IX. Two new species related to leoni Barbosa and reevesi Wirth. Bull Brooklyn Entomol Soc 51: 45-52.

Wirth WW, Blanton FS 1956d. Studies in Panama Culicoides VII. The species of the pulicaris and cova-garciai groups (Diptera: Heleidae). Proc Entomol Soc Washington 58: 211-227.

Wirth WW, Blanton FS 1959. Biting midges of the genus Culicoides from Panama (Diptera: Heleidae). Proc U S Nat Mus 109: 237-482.
Wirth WW, Blanton FS 1968. A revision of the neotropical biting midges of the hylas group of Culicoides (Diptera: Ceratopogonidae). Fla Entomol 51: 201-215.

Wirth WW, Blanton FS 1970. A review of the Culicoides Nigrigenus group, with two new species (Diptera: Ceratopogonidae). Entomol News 81: 141-151.

Wirth WW, Blanton FS 1973. A review of the maruins or biting midges of the genus Culicoides (Diptera: Ceratopogonidae) in the Amazon Basin. Amazoniana 4: 405-470.

Wirth WW, Blanton FS 1974. The West Indian sandflies of the genus Culicoides (Diptera: Ceratopogonidae). US Dept Agric Tech Bull 1474: 1-98.

Wirth WW, Dyce AL, Spinelli GR 1988. An atlas of wing photographs, with a summary of the numerical characters of the neotropical species of Culicoides (Diptera: Ceratopogonidae). Contrib Am Entomol Inst 25: 1-72.

Wirth WW, Felippe-Bauer ML 1989. The neotropical biting midges related to Culicoides paraensis (Diptera: Ceratopogonidae). Mem Inst Oswaldo Cruz 84: 551-565. 